\title{
Uji Toksisitas Ekstrak Etanolik Batang Tanaman Majapahit (Crescentia cujete) Terhadap Artemia salina Leach
}

\author{
Rahma Diyan Martha*, Fatimah \\ Faculty Pharmacy, STIKes Karya Putra Bangsa, Tulungagung, Indonesia \\ *Correspondence Email : rahma100291@gmail.com
}

\begin{abstract}
Cancer is a disease characterized by uncontrolled cell growth and the ability of these cells to attack biological tissue. Various attempts have been made, one of them with treatment to kill cancer cells, but not a few of these efforts actually cause side effects. This fact demands the need for a safe alternative way to treat cancer using natural ingredients. One of thelocal natural resourcesthat has the potential to treat cancer is Majapahit (Crescentia cujete). In this study, Majapahit (C. cujete) stem extracts were carried out which haveanticancer activity. The firststage was screening by conducting a qualitative analysis of the ethanol extract of the stem of the majapahit plant (C. cujete). Furthermore, a toxicity test was carried out against Artemia salina Leach using the Brine Shrimp Let hality Test (BST) method. Phytochemical testing was carried out to check the content of secondary metabolite compounds contained in the majapahit stem extract, and the results were positive for flavonoids, tannins, saponins and phenolics. This data, supported by spectrophotometric tests, proved that thelargestconcentration of the ethanolic extract of the majapahit(C. cujete) stem was 24.05\% tannin. Then the LC50 test from the toxicity test of the active component ofmajapahitplantstem extract (C.cujete) against Artemia salina Leach showed a concentration of $0.01 \mu \mathrm{g} / \mathrm{mL}$ and $0.04 \mu \mathrm{g} / \mathrm{mL}$, namely with a percentage below $50 \%$.
\end{abstract}

Keywords: Majapahit(C. cujete), Anticancer, Artemia salina Leach, Brine Shrimp Lethality Test (BST)

\begin{abstract}
Abstrak
Kanker merupakan suatu penyakit yang ditandai dengan pertumbuhan sel yang tidak terkendali serta kemampuan sel-sel tersebut untuk menyerang jaringan biologis.Berbagai usaha telah dilakukan, salah satunya dengan pengobatan untuk membunuh sel-sel kanker, namun tidak s edikit usaha tersebut justru menimbulkan efek samping. Kenyataan ini menuntut perlunya cara alternatif yang aman untuk pengobatan penyakit kanker dengan menggunakan bahan al ami.Salah satu sumber alam lokal yang berpotensi untuk pengobatan penyakit kanker adalah Majapahit (Crescentia cujete).Pada penelitian ini dilakukan ekstrak batang Majapahit (C. cujete) yang memiliki aktivitas antikanker. Tahap pertama dilakukan screening dengan cara melakukan analisa kualitatif ekstrak etanol batang tanaman majapahit (C. cujete). Selanjutnya, dilakukan uji toksisitas terhadap Artemia salina Leach dengan metode Brine Shrimp Lethality Test (BST).Pengujian fitokimia dilakukan untuk memeriksa kandungan senyawa metabolit sekunder yang terkandung dalam ekstrak batang majapahit, dan didapatkan hasil positif mengandung flavonoid, tanin, saponin dan fenolat. Data ini, didukung dengan uji spektrofotometri, yang membuktikan bahwa konsentrasi terbesar dari eks trak etanolik batang tanaman majapahit (C. cujete) adalah tanin sebesar 24,05\%. Selanjutkan di uji LC50 dari pengujian toksisitas komponen teraktif ekstrak batang tanaman majapahit (C. cujete) terhadap Artemia salina Leach menunjukkan pada konsentrasi $0,01 \mu \mathrm{g} / \mathrm{mL}$ dan $0,04 \mu \mathrm{g} / \mathrm{mL}$ yaitu dengan persentase dibawah $50 \%$.

Kata Kunci : Tanaman Majapahit (C. cujete), Antikanker, Artemia salina Leach, Brine Shrimp Lethality Test(BST)
\end{abstract}

Received: 15 September 2020, Accepted : October 2020 - Jurnal Photon Vol.11 No.1

DOI : https://doi.org/10.37859/jp.v11i1.2146

PHOTON is licensed under a Creative Commons Attribution-ShareAlike 4.0 International License 


\section{Introduction}

Kanker merupakan suatu penyakit yang menempati peringkat tertinggi sebagai penyebab kem atian di dunia, khususnya di negara-negara berkembang (Indrayani et al., 2006). Penyakit ini ditandai dengan pertumbuhan sel yang tidak terkendali serta kemampuan sel-sel tersebut untuk meny erang jaringan biologis lainnya, baik dengan pertumbuhan langsung pada jaringan yang bersebelahan (invasi) atau dengan migrasi sel ke tempat yang jauh (metastasis) di dalam tubuh (Meiyanto et al., 2006). Berbagai usaha telah dilakukan untuk menanggulangi berbagai penyakit kanker seperti pembedahan, radioterapi, dan kemoterapi sitostatik. Pengobatan ini dilakukan untuk membunuh selsel kanker, namun tidak sedikit usaha tersebut justru menimbulkan efek samping (Moeljo pawi ro et al., 2007). Kenyataan ini menuntut perlunya cara alternatif yang aman untuk pengobatan penyakit kanker dengan menggunakan bahan alami.

Salah satu sumber alam lokal yang berpotensi untuk pengobatan penyakit kanker adalah Majapahit (Crescentia cujete). Tanaman majapahit di Indonesia kurang begitu mendapatkan perhatian dan belum begitu banyak dimanfaatkan, dikarenakan buahnya yang pahit dan bau yang menyengat. Pada ekstrak buah majapahit, diketahui memiliki komponen metabolit berupa; tanin, fenol, saponin, alkaloid, flavanoid, antrakuinon, cardenolides (cardia glikosida), dan phiobatanin (Ejelonu et al, 2011). Senyawa antikanker yang berasal dari bahan al am diketahui memiliki tingkat toksisitas yang rendah untuk penanganan kanker jika dibandingkan dengan kemoterapi yang sering dilakukan sebagai metode pengobatan kanker.

Pada penelitian ini dilakukan ekstrak batang Majapahit (C. cujete) yang memiliki aktivitas antikanker. Tahap pertama dilakukan screening dengan cara melakukan analisa kualitatif ekstrak etanol batang tanaman majapahit (C. cujete). Selanjutnya, dilakukan uji toksisitas terhadap Artemia salina Leach dengan metode Brine Shrimp Lethality Test (BST) yang merupakan uji pendahuluan yang dapat digunakan untuk memantau senyawa bioaktif dari bahan alami (Anderson etal., 1991). Adanya korelasi positif antara metode BST dengan uji sitotoksik menggunakan kultur sel kanker maka metode ini sering dimanfaatkan untuk skrining senyawa antikanker (Carballo et al., 2002). Metode tersebut memiliki beberapa keuntungan antara lain lebih cepat, murah, mudah, tidak memerlukan kondisi aseptis dan dapat dipercaya (Fajarningsih et al., 2006).

Berdasarkan uraian latar belakang di atas maka perlu dilakukan penelitian dengan judul "Uji Toksisitas Ekstrak EtanolikBatang Tanaman Majapahit (C. cujete) terhadap A. Salina Leach". Hasil analisa kualitatif dan kuantitatif mengenai senyawa potensial antikanker pada ekstrak batang

Received: 15 September 2020, Accepted : October 2020 - Jurnal Photon Vol.11 No.1 DOI : https://doi.org/10.37859/jp.v11i1.2146 
tanaman majapahit (C. cujete) dapat diketahui, sehingga mempermudah proses lebih lanjut kearah pengembangan obat dan terapi pengobatan kanker berbasis senyawa bahan alam.

\section{The Methods}

Metode penelitian yang digunakan dalam penelitian ini adalah eksperimen atau percobaan. Pengujian kuantitatif senyawa potensial antikanker pada bagian batang tanaman majapahit (C.cujete) dilakukan dengan menggunakan uji fitokimia dan spektrofotometer. Senyawa yang memiliki potens i antikanker yang menjadi target dalam penelitian ini, meliputi; flavanoid, tanin, saponin, dan fenol at. Digunakan uji toksisitas akut terhadap larva Artemia salina Leach sebagai hewan coba dengan metode Brine Shrimp Lethality Test (BST) yang merupakan bioassay pertama penelitian bahan alam, dengan rentang waktu selama 24 jam setelah pemberian dosis uji dan ditentukan nilai LC50, dimana terjadi kematian pada 50\% hewan coba.

\section{Result and Discussion}

Sampel yang digunakan adalah sampel kering batang tanaman majapahit (C. cujete). selama proses pengeringan terdapat perubahan salah satunya warna dan tekstur. Pembuatan ekstrak batang tanaman majapahit (C. cujete)menggunakan metode maserasi. Menurut Kiswando (2011) metode maserasi digunakan karena tidak memerlukan peralatan yang rumit atau alat yang digunakan sederhana, relatif murah, dan dapat menghindari penguapan komponen senyawa karena tidak menggunakan panas. Selain itu, metode ini hanya tergantung oleh lamanya waktu kontak antara pelarut dengan sampel, dan kepolaran pelarutnya.

Pengujian fitokimia yang dilakukan meliputi pengujian adanya flavonoid, tanin, saponin dan fenol at. Pengujian fitokimia dilakukan untuk memeriksa kandungan senyawa metabolit sekunder yang terkandung dalam ekstrak batang majapahit. Pengujian fitokimia dapat dilihat pada Tabel 1, dibawah ini:

Tabel 1. Uji Fitokimia Ekstrak Batang Majapahit

\begin{tabular}{lcccc}
\hline \multicolumn{1}{c}{ Sampel } & \multicolumn{4}{c}{ Senyawa Metabolit Sekunder } \\
\hline Ekstrak Batang & Flavonoid & Tanin & Saponin & Fenolat \\
Majapahit & + & + & + & + \\
\hline
\end{tabular}

Keterangan $\quad:+=$ ada kandungan zat yang dianalisis

- = tidak ada kandungan zat yang dianalisis

Berdasarkan hasil yang ditunjukkan pada Tabel diatas, diperoleh hasil positif adanya flavonoid, tanin, saponin dan fenolat. Identifikasi flavonoid pada batang majapahit dinyatakan positif, karena

Received: 15 September 2020, Accepted : October 2020 - Jurnal Photon Vol.11 No.1

DOI : https://doi.org/10.37859/jp.v11i1.2146

PHOTON is licensed under a Creative Commons Attribution-ShareAlike 4.0 International License 
setelah penambahan bubuk $\mathrm{Mg}$ dan beberapa tetes $\mathrm{HCl}$ pekat terbentuk warna merah. Identifikasi adanya kandungan tanin ditandai dengan terbentuknya warna biru kehitaman pada filtrat batang majapahit dalam akuades ketika dicampurkan dengan pereaksi besi (III) klorida. Pada penelitian ini diperoleh hasl positif, dimana setelah dicampurkan dengan pereaksi besi (III) klorida warna berubah menjadi biru kehitaman.

Pada identifkasi saponin diperoleh hasil positif, dimana menghasilkan busa stabil dan ti dak hilang apabila ditambahkan $\mathrm{HCl} 2 \mathrm{~N}$. Hasil yang diperoleh dalam penelitian ini, ketika dilakukan pengocokan secara vertical terlihat busa yang stabil. Identifikasi kandunganfenolat pada batang majapahit dinyatakan positif, karena setelah dilarutkan dengan metanol dan ditambahkan $2 \mathrm{~mL}$ larutan besi (III) klorida 10\% dalam air atau etanol sebanyak $2 \mathrm{~mL}$, menghasilkan warna hijau kebiruan. Sehingga dapat disimpulkan uji fitokimia pada batang majapahit positif mengandung senyawa metabolit sekunder.

Pengujian kuantitatif senyawa potensial antikanker pada batang tanaman majapahit (C.cujete) dilakukan dengan menggunakan spektrofotometer. Senyawa yang memiliki potensi antikanker y ang menjadi target dalam penelitian ini, meliputi; flavanoid, tanin, saponin, dan fenolat. Flavanoid merupakan metabolitsekunder yang dihasilkan pada tanaman. Flavanoid memil iki empatkelompok besar, yaitu; flavanol, flavone, anthocyanidine,dan isoflavonoid (Veeramuthu et al,2017). Kel o mp ok besar flavanoid terdiri atas beberapa jenis senyawa yang termasuk didalamnya. Tanin merupakan salah satu bahan alam yang banyak ditemukan pada tanaman. Tanin masuk dalam senyawa fenolik yang memiliki berat molekul besar, serta larut dalam air dan alkohol. Saponin merupakan gli ko si da alami yang memiliki berbagai sifat farmakologis, salah satunya aktivitas sitotoksik. Saponin tidak hanya tersebar pada tanaman tingkat tinggi tetapi juga terdapat pada hewan, seperti; invertebrata laut (Podolak et al., 2010). Tanaman majapahit (C. cujete) merupakan salah satu tanaman tingkat tinggi yang diduga memiliki kandungan saponin didalamnya. Fenolat merupakan jenis metabolit sekunder yang terbanyak ditemukan pada tanaman (Lin et al., 2016). Konsentrasi fenol pada tanaman berbeda-beda, dan banyak faktor yang mempengaruhnya. Hasil analisis spektrofoto meter konsentrasi flavanoid, tanin, saponin, dan fenolat pada ekstrak etanolik batang tanaman majapahit (C.cujete) dapat dilihat Tabel 2.

Tabel 2. Hasil Analisis Spektrofotometer Ekstrak Batang Tanaman Majapahit

\begin{tabular}{|c|c|c|}
\hline No. & Senyawa Target & Persentase \\
\hline 1 & Flavonoid & 9,91 \\
\hline 2 & Tanin & 24,05 \\
\hline 3 & Saponin & 9,30 \\
\hline 4 & Fenolat & 13,85 \\
\hline
\end{tabular}

Received: 15 September 2020, Accepted : October 2020 - Jurnal Photon Vol.11 No.1 DOI : https://doi.org/10.37859/jp.v11i1.2146 
Berdasarkan diatas, diketahui bahwa konsentrasi terbesar dari ekstrak etanolik batang tanaman majapahit (C. cujete) adalah tanin. Tanin sendiri dapat ditemukan pada akar, kulit pohon, batang, dan bagian luar dari jaringan tanaman (Yildirim and Turkan, 2015). Senyawa tanin pada tumbuhan, merupakan senyawa yang berfungsi sebagai pelindung tanaman, yakni; melindungi dari UV yang menyebabkan kerusakan, mencegah adanya radikal berbahaya yang merusak struktur sel (Riedl et al., 2001). Tanin diketahui juga memiliki efek antibakteri, antioksidan, dan antikanker. Sehingga, tanin mulai dikembangkan potensinya sebagai senyawa antikanker. Terdapat sekitar 57 jenis tanin dan senyawa yang berhubungan dengan tanin, termasuk; gallotannin, ellagitanin, dan tannin kompleks. Senyawa tersebut telah di evaluasi kemampuan sitotoksiknya terhadap sel line tumor manusia, yang meliputi; malignan melanoma, karsinoma paru, ileocal adenokarsinoma, dan sel line medulloblastoma (Kashiwada et al., 1992). Pada penelitian yang dilakukan (Booth et al., 2013) diketahui bahwa tannin menginduksi terjadinya apoptosis pada kanker payudara dengan cara mengaktivasi caspase $3 / 7$ dan caspase 9 .

Berdasarkan beberapa penelitian tersebut, terbukti tanin memiliki efek positif sebagai antikanker. Sehingga, tanaman majapahit (C. cujete) memiliki potensi untuk diteliti lebih jauh akan potensinya sebagai tanaman potensial antikanker. Tanin sebagai salah satu senyawa ptensial antikanker pada tanaman majapahit, bisa diisolasi dari batang tanaman. Hal, tersebut dikarenakan tanin banyak terdistribusi pada batang tanaman.

Konsentrasi terkecil dari ekstrak etanolik batang tanaman majapahit (C. cujete) adalahsaponin. Akumulasi senyawa saponin berbeda-beda pada bagian tanaman, pada spesies yang berbeda, seperti; pada biji spesies Hippocastani, pada akar spesies ginseng, kulit batang Quillaja, pada biji kedelai (Glycine max), pada akar dan bunga Primulae, pada daun Herniae, pada umbi Dioscorea villosa (Kregiel et al., 2017). Saponin pada tanaman memiliki banyakaktifitas biologis bagi tanaman, yakni sebagai pelindung tanaman (antimikroba dan antiherbivore) (Ousbourn, 1996). Saponin juga diketahui memiliki aktifitas antifungi sebagai pelindung tanaman dari serangan jamur patogen. Saponin juga diketahui memiliki aktifitas antioksidan dan antikanker. Senyawa triterpen saponin memiliki aktivitas antiproliferasi (Masullo etal.,2014). Sehingga, berdasarkan peneliti an ters ebut, saponin terbukti memiliki potensi sebgai antikanker, sehingga tanaman majapahit (C.cujete) juga dapat memiliki potensi sebagai salah satu penghasil antikanker berbasis bahan alam.

Jumlah kematian larva udang pada setiap tabung uji dalam berbagai konsentrasi perlakuan ekstrak batang tanaman majapahit ditunjukkan pada Tabel...dari Tabel tersebut dapat diketahui bahwa

Received: 15 September 2020, Accepted : October 2020 - Jurnal Photon Vol.11 No.1 DOI : https://doi.org/10.37859/jp.v11i1.2146 
berbagai konsentrasi ekstrak batang tanaman majapait memperlihatkan pengaruh yang berbeda terhadap kematian larva udang. Hasil penelitian disajikan pada Tabel 3, dibawah ini:

Tabel 3. Pengaruh Berbagai Konsentrasi Ekstrak Batang Tanaman Majapahit Terhadap Larva Artemia $s$. Leach

\begin{tabular}{|c|c|c|c|c|c|c|}
\hline \multirow{2}{*}{$\begin{array}{l}\text { Replikasi } \\
\text { ke- }\end{array}$} & \multicolumn{4}{|c|}{ Jumlah Kematian Larva Tiap Konsentrasi } & \multirow{2}{*}{ Kontrol (-) } & \multirow{2}{*}{$\begin{array}{c}\text { Volume } \\
\text { Akhir } \\
\text { Media }\end{array}$} \\
\hline & $\begin{array}{c}0,01 \\
\mu \mathrm{g} / \mathrm{mL}\end{array}$ & $\begin{array}{c}0,04 \\
\mu \mathrm{g} / \mathrm{mL}\end{array}$ & $\begin{array}{c}0,07 \\
\mu \mathrm{g} / \mathrm{mL}\end{array}$ & $\begin{array}{c}0,10 \\
\mu \mathrm{g} / \mathrm{mL}\end{array}$ & & \\
\hline 1 & 2 & 3 & 5 & 7 & 0 & $5 \mathrm{~mL}$ \\
\hline 2 & 1 & 3 & 5 & 8 & 0 & $5 \mathrm{~mL}$ \\
\hline 3 & 1 & 5 & 7 & 9 & 0 & $5 \mathrm{~mL}$ \\
\hline $\begin{array}{c}\text { Total } \\
\text { Kematian }\end{array}$ & 4 & 11 & 17 & 24 & 0 & - \\
\hline Rata-Rata & 1,3 & 3,6 & 5,6 & 8,0 & 0 & - \\
\hline $\begin{array}{l}\text { Persentase } \\
\text { Kematian }\end{array}$ & $13 \%$ & $36 \%$ & $56 \%$ & $80 \%$ & $0 \%$ & - \\
\hline
\end{tabular}

Jumlah larva tiap tabung uji dengan tiga replikasi adalah 30 ekor. Jumlah total larva udang yang digunakan adalah 90 ekor larva. Total kematian diperoleh dengan menjumlahkan larva yang mati pada setiap konsentrasi, sedangkan rata-rata kematian larva diperoleh dengan membagi total kematian larva pada tiap konsentrasi dengan jumlah replikasi yang dilakukan. Dari Tabel tersebut dapat diketahui bahwa berbagai konsentrasi ekstrak etanol batang majapahit memperlihatkan pengaruh yang berbeda terhadap kematian larva, yaitu semakin besar konsentrasi ekstrak batang majapahit, juga diikuti dengan semakin besar kematian larva. Menurut Indayani (2016), ekstrak yang aman digunakan dengan tingkat kematian larva kurang dari 50\%.Dari tabel tersebut dapat diketahui ada dua persentase dibawah 50\%, yaitu 13\% dan 36\%. Sehingga dapat dikatakan bahwa ekstrak batang majapahit pada konsentrasi $0,01 \mu \mathrm{g} / \mathrm{mLdan} 0,04 \mu \mathrm{g} / \mathrm{mL}$ aman untuk digunakan.

\section{Conclusion}

Pengujian fitokimia yang dilakukan meliputi pengujian adanya flavonoid, tanin, saponin dan fenolat. Pengujian fitokimia dilakukan untuk memeriksa kandungan senyawa metabolit sekunder yang terkandung dalam ekstrak batang majapahit, dan didapatkan hasil positif mengandung flavonoid, tanin, saponin dan fenolat. Data ini, didukung dengan uji spektrofotometri, yang membuktikan bahwa konsentrasi terbesar dari ekstrak etanolik batang tanaman majapahit (C. cujete) adalah tanin

Received: 15 September 2020, Accepted : October 2020 - Jurnal Photon Vol.11 No.1

DOI : https://doi.org/10.37859/jp.v11i1.2146

PHOTON is licensed under a Creative Commons Attribution-ShareAlike 4.0 International License 
sebesar $24,05 \%$. Selanjutnya diikuti dengan senyawa fenolat $13,85 \%$, senyawa flavonoid $9,91 \%$ dan senyawa saponin 9,30\%. Selanjutkan di uji LC50 dari pengujian toksisitas komponen teraktif ekstrak batang tanaman majapahit (C. cujete) terhadap Artemia salina Leach menunjukkan pada konsentrasi $0,01 \mu \mathrm{g} / \mathrm{mL}$ dan $0,04 \mu \mathrm{g} / \mathrm{mL}$ yaitu dengan persentase dibawah $50 \%$.

\section{References}

Anderson, J.E., Goetz, C.M., McLaughlin, J.L., and Suffness, M. (1991). A Blind Comparison of Simple Bench-top Bioassays and Human Tumour Cell Cytotoxicities as Antitumor Prescreens. Phytochem Analysis (2): 107-111.

Astuti, P., S.Utami, T. Pratiwi, T. Hertiani, G. Alam , A.Tahir dan S.Wahyono. (2005). Antimicrobial Activity Screening of Marine Sponges Extracts Colected from Barang Lomposea. Journal of Traditional Medicine (10): 32.

Abotaleb, M., Samsons, M.S., Elizabeth, V., Sharon, V., Peter, K., Alena L., Dietrich, B. (2019). Flavanoids in Cancer and Apoptosis. Cancers.11.

Bachran, C., Silke, B., Mark, S., Diana, B., Hendrik, F. (2008). Saponins in Tumor Therapy. Mini Rev. Med. Chem. 8: 575-584.

Burkill, H. M. (1985). The Useful Plants of Tropical West Africa. 2 Edn. Richmond, UK, Kew Royal Botanical Garden, London.

Carballo, J.L., Inda, Z.L.H, Perez, P, dan Gravalos, M.D.G. (2002). A Comparison Between Two Brine Shrimp Assays to Detect In Vitro Cytotoxicity in Marine Natural Products. BMC Biotechnology 2 (17) : 1-5.

Dwiatmaka, Y. (2001). Identifikasi Simplek dan Toksisitas AkutSecara BST Ekstrak Batang Pule (Alstonia scholaris). Program Pasca Sarjana Universitas Gadjah Mada, Yogyakarta.

Damyanov, C. A., Ivan, K. M., ladimir, S. P., Lactchezar, A. 2018. Conventional Treatment of Cancer Realities and Problems. Annalas of Complementary and Alternative Medicine. 1:1-9.

Ejelonu, B. C., Lasisi, A. A., Ejelonu, O. C. (2011). The Chemical Constituents of Calabash (Crescentia cujete). AfricanJournal of Biotechnology. 10: 19631-19636.

Fajarningsih, N.D., Januar, H.I, Nursid, M dan Wikanta, T. (2006). Potensi Antitumor Ekstrak Spons Crella papilata Asal Taman Nasional Laut Kepulauan Seribu. Jurnal Pascapanen dan Bioteknologi Kel autan dan Perikanan. Vol 1 (1): 35-41.

Gu, Z.M., Zeng. L, J.T. Schwedler, K.V.Wood dan J.L. McLaughlin. (1995). New Bioactive Adjacent bi s -THF Annonaceous Acetogenins from Annona Bullata. Phytochemistry:40.

Greenwell, M. and Rahman, P. K. S. M. (2015). Medicinal Plants: Their Use In Anticancer Treatment. International Journal of Pharmaceutical Sciences and Research. 6:4103-4112.

Hasamah, U., Desi, R., Syaefudin. (2017). Antibacterial Activity of Ethanol Extract from Stem Bark and Leaves of Berenuk (Crescentia cujete L.). Current Biochemistry. 4:1-14.

Hanahan, D. And Robert, A. W. (2011). Hallmarks of Cancer:The Next Generation. Cell. 144: 646-674.

Huang,S. W., Jin, C. L., Sheng,C.K., Tur,F.H. (2014). PPemd26, an Anthraquinone Derivative, Suppresses Angiogenesis via Inhibiting VEGFR2 Signalling. British Journal of Pharmacology . 171: 5728-5742.

Indrayani, L., S. Hartati, dan S. Lydia. (2006). Skrining Fitokimia dan Uji Toksisitas Ekstrak Batang Pec ut Kuda (Stachytarpheta jamaicensis L. Vahl) Terhadap Larva Udang Artemia salina Leach. Berkas Penelitian Hayati (12): 57-61.

Received: 15 September 2020, Accepted : October 2020 - Jurnal Photon Vol.11 No.1

DOI : https://doi.org/10.37859/jp.v11i1.2146

PHOTON is licensed under a Creative Commons Attribution-ShareAlike 4.0 International License 
Kanwar, A.S. (2007). Brine Shrimp (Artemia salina) a Marine Animal for Simple and Rapid Biological Assays. Chinese Clinical Medicine 2 (4):35-42.

Kiswandono, Abadi. (2011).Skrinning Senyawa Kimia dan Pengaruh Metode Maserasi dan Refluks pada Biji Kelor (Moringa olifera, Lamk) terhadap Rendemen Ekstrak yang dihasilkan.Jurnal Sains Natural Universitas Nusa Bangsa. Vol. 1, No. 2, p.126-134.

Maira, Fz. (1999). Instituto de Ecología y Sistemática (Academia de Ciencias de Cuba). La Habana: Editorial Academia.

Mukhtar, M.H., A.Z, Adnan dan M.W, Pitra. (2007). Uji Toksisitas Minyak Atsiri Batang Kemangi (Ocimum basilicum L.) dengan Metode Uji Brine Shrimp Lethality Bioassay.Jurnal Sains Teknologi Farmasi.Vol 12(1): $1-4$.

Meiyanto, E., Supardjan, Da'i, M, dan Agustina, D. (2006). Efek Antiproliferatif Pentagamavunon-0 terhadap Sel Kanker Payudara T47D. Jurnal Kedokteran Yarsi. 14 (1) : 011-015.

Moeljopawiro, S., M. R. Anggelia. D, Ayuningtyas. B, Widaryanti.Y, Sari, dan I. M, Budi. (2007). Pengaruh Sari Buah Merah (Pandanus conoideus Lam.) Terhadap Pertumbuhan Sel Kanker Payudara dan Sel kanker Usus Besar. Berkala Ilmiah Biologi.Vol 6(2):121-130.

Olaniyi, M. B., Ibraheem, O. L., Aishat, A. O. (2018). Proximate, Phytochemical Screening and Mineral Analysis of Crescentia cujete L. Leaves. Journal of Medicinal Plants for Economic Development. 2.

Parvin, M.S., Das, N., Jahan, N., Akhter, M.A., Nahar, L., Islam, M. E. (2015). Evaluati on of In Vitro Anti Inflammatory and Antibacterial Potential of Crescentia cujete Leaves and Stem Bark. BMC Research Notes. 8: 412-418.

Pongrakhananon, V. (2013). Anticancer Properties of Cardiac Glycosides. Cancer Treatment Conventional and Innovative Approaches.

Ravishankar, D., Rajora, A.K., Greco, F., Osborn, H.M.I. (2013). Flavonoids as prospective compounds for anti-cancer therapy. Int. J. Biochem. Cell Biol.45: 2821-2831.

Sun, H.X., Y. Xie and Y.P. Ye, (2009). Advances in Saponin-Based Adjuvants. Vaccine. 27:1787-1796.

Smith, B. A. and Dollear, F. G. (1947). Oil From Calabash Seed, Crescentiacujete L. The Journal of The American Oil Chemist.

Sukardiman., R. Abdul dan P.N. Fatma. (2004). Uji Praskrining Aktivitas Antikanker Ekstrak Eter dan Ekstrak Metanol Marchantia planiloba Steph. Dengan Metode Uji Kematian Larva Udang dan Profil Densitometri Ekstrak Aktif. Majalah Farmasi Airlangga 4 (3): 97-100.

Silva, T.M., Nascimento, R.J., Batista, M.B., Agra, M.F., dan Camara, C.A. (2007). Brine shrimp bi oas say of some species of solanum from northeastern brazil. Revista Brasileira de Farmacognosia (17) Hal: 35 38.

Sunarni., Iskamto dan Suhartinah. (2003). Uji Toksisitas dan Anti Infeksi Ekstrak Etanol Buah Brucea sumatrana Roxb. Terhadap Larva Udang Artemia salina Leach. dan Staphylococcus aereus. Bio smart 5 (4): 65-67.

Steenis, V. (1974). Flora Malesina Vol 8 Sijthoff and Noordhoff International Publisher: Netherland.

Theis, M., Melinda, R., Kristin, B., Teresa, D. G. (2017). Crescentia cujete (Calabash Tree) Seed Extract and Fruit Pulp Juice Contract Isolated Uterine Smooth Muscle Tissues FromMus musculus. Journal of Medical Plants Studies. 5:10-15.

Widodo, S. H. (2001). Crescentia cujete L. In: Bunyapraphatsara N, van Valkenburg JLCH (eds) Plant resources of south- east Asia (PROSEA), no. 12(2), medicinal and poisonousplants. Pudoc, Wageningen, pp 193-194.

Received: 15 September 2020, Accepted : October 2020 - Jurnal Photon Vol.11 No.1 DOI : https://doi.org/10.37859/jp.v11i1.2146

PHOTON is licensed under a Creative Commons Attribution-ShareAlike 4.0 International License 
Vuong, Q.V., S. Hirun, T.L.K. Chuen, C.D. Goldsmith and S. Murchie et al., (2014). Antioxidant and anticancer capacity of saponin-enriched Carica papaya leaf extracts. Int. J. Food Sci. Technol.50: 169177.

Received: 15 September 2020, Accepted : October 2020 - Jurnal Photon Vol.11 No.1 DOI : https://doi.org/10.37859/jp.v11i1.2146

PHOTON is licensed under a Creative Commons Attribution-ShareAlike 4.0 International License 